\title{
Determination of Viral Load by Quantitative Real-Time PCR in Herpes Simplex Encephalitis Patients
}

\author{
Shradha S. Bhullar ${ }^{a}$ Nitin H. Chandak ${ }^{a}$ Hemant J. Purohit ${ }^{b}$ Girdhar M. Taori $^{a}$ \\ Hatim F. Daginawala ${ }^{a}$ Rajpal S. Kashyap ${ }^{a}$ \\ a Biochemistry Research Laboratory, Central India Institute of Medical Sciences, and b Environmental Genomics Unit, \\ National Environmental Engineering Research Institute, Nagpur, India
}

\section{Key Words}

Herpes simplex virus · Herpes simplex encephalitis .

Quantitative real-time PCR · Viral load · Molecular

diagnostics

\begin{abstract}
Objective: Human herpesviruses cause various acute, subacute, and chronic disorders of the central nervous system and peripheral nervous systems in adults and children. The objective of the present study is to summarize the experience gained with the estimation of viral load in the central nervous system of children and adults with herpes simplex encephalitis (HSE) admitted to a neurological institute at Nagpur, India, by quantitative real-time PCR (qPCR) assay within the past 4 years. Methods: The qPCR assay was evaluated retrospectively in 242 cerebrospinal fluid (CSF) samples from patients. Evaluation of possible relationships was done between the herpes simplex virus (HSV) DNA concentration in CSF with that of patients' clinical and laboratory manifestations. The prevalence of the type of HSV in the study population was also determined using type-specific real-time PCR analysis. Results and Conclusions: Real-time analysis using type-specific primers revealed the presence of predominantly HSV-1 genotype in the study population. The QPCR results show that in patients with higher viral loads in
\end{abstract}

\section{KARGER}

(c) 2013 S. Karger AG, Basel

0300-5526/14/0571-0001\$39.50/0

E-Mail karger@karger.com

www.karger.com/int their CSF, a greater number of cases were associated with the presence of lesions in the brain as revealed by computed tomography/magnetic resonance imaging scan. They required acyclovir therapy for a longer duration and had a poorer clinical outcome than the patients with lower viral loads in their CSF.

Copyright $\odot 2013$ S. Karger AG, Basel

\section{Introduction}

Human herpesviruses cause various acute, subacute, and chronic disorders of the central nervous system (CNS) and peripheral nervous systems in adults and children. Among herpesviruses, herpes simplex virus (HSV)1 and -2 cause a wide spectrum of clinical manifestations like meningitis, encephalitis, myelitis, etc., in the CNS of infants as well as adults.

Molecular diagnostic assays using polymerase chain reaction (PCR) are the standard methods for detecting herpesvirus infections of the CNS. HSV DNA detection in cerebrospinal fluid (CSF) is used to define CNS infection and PCR testing of CSF has become gold standard [1-3].

PCR analysis by real-time monitoring of DNA amplification reactions has previously been described [4]. Since 
real-time PCR allows a rapid detection of viral genomes in clinical specimens and is easy to use in a clinical laboratory, different real-time PCR assays for the detection of HSV have been developed [5-7]. On the other hand, a quantitative system using real-time PCR assay has recently been developed to measure viral load of HSV [8-11]. Quantification of HSV DNA has also been used as a means of evaluating the antiviral effects of candidate drugs [12]. Quantification of viral load may be useful for assessing the prognosis and may provide additional information for management of HSV infection.

There are very few documented studies for determining the incidence of herpes simplex encephalitis (HSE) in India [13-15]. In the present study, a quantitative realtime PCR assay (qPCR) for HSV was evaluated in a 4-year retrospective study that included children and adults with herpes simplex infection of the CNS admitted to a neurological institute at Nagpur, India. The qPCR assay was evaluated retrospectively in 242 CSF samples from patients with the aim to study the concentration of HSV genome as a prognostic marker. The prevalence of the type of HSV in the study population was also determined using type-specific real-time PCR analysis. The aim is to investigate the range of the HSV genome concentration in initial samples and to evaluate possible relationships between the HSV DNA concentration in CSF with that of patients' clinical and laboratory manifestations. The age, gender, duration of disease, and severity of disease for patients with high and low viral load were compared. The effect of acyclovir therapy on the levels of HSV DNA was determined for 4 patients. The objective of this paper is to summarize the experience gained with the estimation of viral load in the CNS of patients with HSE at our institute by qPCR assay within past 4 years.

\section{Materials and Methods}

\section{Patient Selection and Samples Collection}

The Central India Institute of Medical Sciences (CIIMS), Nagpur, is a tertiary referral center. Patients with suspected cases of HSE who were admitted were enrolled in this study. Criteria for suspicion of HSE were the presence of fever, altered mental status (low level of consciousness, behavior or personality changes) and other clinical manifestations (e.g. focal neurological deficits, seizures). Neurological diagnostic investigations were performed during the first week of hospitalization; these investigations included the AFB and Gram stain, bacterial culture, HIV status, determination of the protein, sugar level and cell counts in CSF, computed tomography (CT) scan and magnetic resonance imaging (MRI) of the brain. In CT, plain/contrast imaging of the brain was done, whereas for MRI T1- and T2-weighted, diffusion-weighted imaging and fluid-attenuated inversion recovery images were tak- en. A total of 102 CSF samples of patients initially suspected for HSE were tested using PCR assays. All patients diagnosed with HSE were treated intravenously with acyclovir $(30 \mathrm{mg} / \mathrm{kg}$ b.w./ day) for 8-21 days. The clinical outcome for each patient was assessed. Patients were re-examined at the time of completion of treatment. Morbidity was defined as previously reported [16]. The outcome was assessed in terms of mild, moderate or severe impairment; normal clinical recovery, or death. The initial CSF samples were drawn from all the patients except 2, diagnosed with HSE before treatment with acyclovir. CSF samples were obtained from some of the patients whenever possible during treatment. In addition to that, 140 CSF samples from patients with other viral encephalitis, tuberculous, pyogenic or fungal meningitis and noninfectious neurological disorders such as hypertension, status epilepticus, stroke, etc., were also analyzed to test the specificity of the PCR assays. Clinical data was prospectively collected on case record forms. Informed consent was obtained from all patients. The Institutional Ethics Committee of CIIMS, Nagpur, approved the study.

\section{DNA Extraction}

The genomic DNA was extracted from $200 \mu \mathrm{l}$ of CSF samples from patients by using a ZR Viral DNA kit (Zymo Research, Irvine, Calif., USA) according to the manufacturer's protocol. The viral DNA was eluted from the Zymo-Spin IC columns in a volume of $20 \mu \mathrm{l}$ of elution buffer and was further used in PCR.

\section{Quantitative Real-Time PCR Assay}

The set of primers used for HSV has been described by Cunningham et al. [17] and Lakeman and Whitley [18] (5'-ATC AAC TTC GAC TGG CCC TT- $3^{\prime}$ and $5^{\prime}$-CCG TAC ATG TCG ATG TTC AC- $3^{\prime}$ ) which generate a 179-bp product of the DNA polymerase gene after amplification. Amplification and quantification was done based on the principle of SYBR Green ${ }^{\circledR}$ technology. The amplification reactions were carried out in a total volume of $10 \mu \mathrm{l}$, containing $1 \mu$ l of template DNA, $5 \mu$ l of Power SYBR ${ }^{\circledR}$ Green PCR Master Mix (Applied Biosystems, Foster City, Calif., USA), $1 \mu \mathrm{l}$ each of $(0.5 \mu \mathrm{M})$ forward and reverse primer, and $2 \mu \mathrm{l}$ of sterile water. The amplification conditions consisted of preincubation at $95^{\circ}$ for $10 \mathrm{~min}$ and two steps ( 40 cycles) at $95^{\circ}$ for $15 \mathrm{~s}$ and $65^{\circ}$ for $1 \mathrm{~min}$. The quantification cycle $\left(\mathrm{C}_{t}\right)$ was calculated as the cycle number at which the concentration increase became exponential. The specific target amplification was analyzed by melt-curve analysis of the Applied Biosystems StepOne Real-Time PCR Systems, which consisted of first melting step at $95^{\circ}$ for $15 \mathrm{~s}$, annealing at $60^{\circ}$ for $1 \mathrm{~min}$, and second melting step at $95^{\circ}$ for $15 \mathrm{~s}$.

\section{Standard Curve}

To quantitate viral DNA, a standard curve was obtained for each experiment by co-amplification of known amounts of HSV DNA (determined spectrophotometrically). Seven consecutive dilutions (dilution factor 1:10) were prepared containing from $10^{6}$ to $10^{1}$ copies/reaction. The amounts of HSV DNA in samples were obtained by plotting $\mathrm{C}_{\mathrm{t}}$ values onto the standard curve.

\section{HSV-1 and HSV-2 Real-Time PCR Assay}

US3 gene is found conserved in the US region of HSV genome. This gene encodes a serine/threonine kinase. Primers targeting US3 gene of HSV-1 and HSV-2 were designed to differentiate between the two on the basis of PCR. The set of primers used for HSV-1 were 
( $5^{\prime}$-AACGCGTCCTTGTTCTCGGC- ${ }^{\prime}$ and $5^{\prime}$-TGAGGCGCGATTCTGGATGC- $3^{\prime}$ ) and that of HSV-2 were ( $5^{\prime}$-ATAGCAGCCACCCGAACTACCC- $3^{\prime}$ and $5^{\prime}$-TGACCCCAGAAACGACGTGC-3') which generate 127 - and 144-bp product respectively upon amplification. Amplification was done based on the principle of SYBR Green technology. The amplification reactions were carried out in a total volume of $10 \mu \mathrm{l}$, containing $1 \mu \mathrm{l}$ of template DNA, $5 \mu \mathrm{l}$ of SYBR Green PCR master mix, $1 \mu$ leach of $(0.5 \mu \mathrm{M})$ forward and reverse primer, and $2 \mu \mathrm{l}$ of sterile water. The amplification conditions consisted of preincubation at $95^{\circ}$ for $10 \mathrm{~min}$ and two steps (40 cycles) at $95^{\circ}$ for $15 \mathrm{~s}$ and $58^{\circ}$ for $1 \mathrm{~min}$. The specific target amplification was analyzed by melt-curve analysis which consisted of first melting step at $95^{\circ}$ for $15 \mathrm{~s}$, annealing at $60^{\circ}$ for $1 \mathrm{~min}$, and second melting step at $95^{\circ}$ for $15 \mathrm{~s}$.

\section{Statistical Analysis}

The results are expressed as mean \pm SDs. All the analyses were done by the $\chi^{2}$ test, $t$ test and Fisher's exact test using the MedCalc software for statistical analysis.

\section{Results}

A series of samples was collected from patients with suspicion of HSE, admitted to our institute from 2008 to 2011. Out of a total of 102 CSF samples of patients initially suspected for HSE, 25 CSF samples of HIV-negative individuals were found to be positive for the presence of HSV by real-time PCR assay using primers targeting the DNA polymerase gene, whereas the remaining 77 were found to be negative by the assay. In addition to that, 140 CSF samples from patients with other CNS infectious or non-infectious neurological disorders were found to be negative by the qPCR assay.

A known amount of HSV DNA was taken in tenfold serial dilutions from $10^{6}$ to $10^{1}$ copies of HSV genome to generate a standard curve in the qPCR assay. The limit of detection was found to be 10 copies of HSV genome to be detected by this assay. A linear quantification was achieved with each of the 1-log dilutions of the HSV DNA standards up to 10 copies of the HSV genome. The standard curve had a slope value of -3.708 with a regression coefficient $\left(\mathrm{R}^{2}\right)$ value of 0.997 . The quantification cycle $\left(\mathrm{C}_{\mathrm{q}}\right)$ values from clinical samples were plotted onto the standard curve and the copy number of HSV genome were calculated per milliliter of CSF samples. No amplification was produced in the no-template control reaction consisting of sterile water instead of target template. The melt-curve analysis of the real-time PCR assay showed a $\mathrm{T}_{\mathrm{m}}$ of $85.0-85.5^{\circ}$ whenever there was presence of HSV DNA in the samples.

As shown in table 1, the number of HSV DNA copies detected in the 25 clinical samples varied from $1.2 \times 10^{1}$
Table 1. Age, gender and viral load of patients in the high viral load group (patients 1-13) and the low viral load group (patients 14-25)

\begin{tabular}{llll}
\hline Patient No. & Age, years & Sex & $\begin{array}{c}\text { Number of HSV } \\
\text { copies/ml of CSF }\end{array}$ \\
\hline 1 & 46 & F & $4.1 \times 10^{6}$ \\
2 & 21 & F & $1 \times 10^{5}$ \\
3 & 38 & M & $1.4 \times 10^{4}$ \\
4 & 58 & M & $2.5 \times 10^{4}$ \\
5 & 45 & F & $3.4 \times 10^{4}$ \\
6 & 13 & M & $1.8 \times 10^{4}$ \\
7 & 74 & M & $2 \times 10^{4}$ \\
8 & 52 & M & $8.1 \times 10^{4}$ \\
9 & 53 & M & $7.9 \times 10^{4}$ \\
10 & 50 & F & $5 \times 10^{4}$ \\
11 & 68 & M & $6.1 \times 10^{4}$ \\
12 & 40 & F & $1 \times 10^{4}$ \\
13 & 75 & M & $4 \times 10^{4}$ \\
14 & 58 & M & $1.9 \times 10^{3}$ \\
15 & 45 & M & $6 \times 10^{3}$ \\
16 & 2 & M & $1 \times 10^{3}$ \\
17 & 56 & F & $1 \times 10^{3}$ \\
18 & 58 & M & $1.1 \times 10^{3}$ \\
19 & 25 & F & $1 \times 10^{2}$ \\
20 & 2 & F & $1.1 \times 10^{2}$ \\
21 & 1 & F & $1.7 \times 10^{2}$ \\
22 & 15 & F & $9.9 \times 10^{2}$ \\
23 & 70 & M & $1.2 \times 10^{1}$ \\
24 & 50 & F & $5 \times 10^{1}$ \\
25 & 37 & F & $1.7 \times 10^{1}$ \\
\hline
\end{tabular}

to $4.1 \times 10^{6}$ copies $/ \mathrm{ml}$ of CSF. The age and gender-wise distribution of patients has also been noted in the abovementioned range.

Table 2 shows the division of patients into two groups of high HSV DNA load ( $>10^{4}$ copies $/ \mathrm{ml}$ of CSF) and low HSV DNA load $\left(<10^{4}\right.$ copies $/ \mathrm{ml}$ of CSF). The groups were divided based on the results of a minimum $p$ value approach to predict the moderate to severe clinical manifestation of HSE based on clinical and laboratory investigations. The difference between the mean age of patients in the two respective groups of viral load did not show any significant variation $(\mathrm{p}=0.1284)$. However, the duration that the patient had been ill prior to obtaining the CSF specimen and the duration for which acyclovir had to be administered was significantly more in the higher viral load group compared to that of the lower viral load group ( $\mathrm{p}=0.0115$ and $\mathrm{p}=0.0028$, respectively). On comparing the CT/MRI scan results of the two viral load groups, it was observed that the lower viral load group had a higher percentage of cases (75\%) with normal CT/MRI scan in 
Table 2. Correlation between HSV DNA level and severity of disease

\begin{tabular}{|c|c|c|c|}
\hline Criteria/parameters & $\begin{array}{l}\text { High HSV } \\
\text { DNA } \\
\text { load group }\end{array}$ & $\begin{array}{l}\text { Low HSV } \\
\text { DNA } \\
\text { load group }\end{array}$ & $\mathrm{p}$ value \\
\hline \multicolumn{4}{|l|}{ Seizures } \\
\hline Present & 7 & 5 & \multirow[t]{2}{*}{$1^{\mathrm{a}}$} \\
\hline Absent & 6 & 7 & \\
\hline \multicolumn{4}{|l|}{ Vomiting } \\
\hline Present & 3 & 2 & \multirow[t]{2}{*}{$1^{\mathrm{a}}$} \\
\hline Absent & 10 & 10 & \\
\hline \multicolumn{4}{|l|}{ Headache } \\
\hline Present & 3 & 3 & \multirow[t]{2}{*}{$1^{\mathrm{a}}$} \\
\hline Absent & 10 & 9 & \\
\hline \multicolumn{4}{|l|}{ CT/MRI } \\
\hline Lesions & 11 & 3 & \multirow[t]{2}{*}{$0.0048^{\mathrm{a}}$} \\
\hline Normal & 2 & 9 & \\
\hline \multicolumn{4}{|l|}{ Glasgow Coma Scale } \\
\hline Mild, 13-15 & $2(15.38 \%)$ & $3(25 \%)$ & $0.92^{\mathrm{b}}$ \\
\hline Moderate, 9-12 & $8(61.53 \%)$ & $8(66.66 \%)$ & $0.88^{\mathrm{b}}$ \\
\hline Severe, $\leq 8$ & $3(23.07 \%)$ & $1(8.33 \%)$ & $0.64^{\mathrm{b}}$ \\
\hline Age, years & $48.69 \pm 18.42$ & $34.91 \pm 25.02$ & $0.1284^{\mathrm{c}}$ \\
\hline \multicolumn{4}{|l|}{ Onset of disease before } \\
\hline collecting CSF, days & $8.27 \pm 4.36$ & $4.42 \pm 2.22$ & $0.0115^{\mathrm{c}}$ \\
\hline \multicolumn{4}{|l|}{ Duration of acyclovir } \\
\hline treatment & $15.81 \pm 4.60$ & $10.25 \pm 3.61$ & $0.0028^{c}$ \\
\hline \multicolumn{4}{|l|}{ Clinical outcome } \\
\hline Normal & $1(7.69 \%)$ & $7(58.33 \%)$ & $0.0341^{\mathrm{a}}$ \\
\hline \multicolumn{4}{|l|}{ Mild to moderate } \\
\hline impairment & $11(84.61 \%)$ & $4(33.33 \%)$ & \\
\hline Severe impairment & $1(7.69 \%)$ & 0.0 & \\
\hline Death & $1(7.69 \%)$ & $1(8.33 \%)$ & \\
\hline
\end{tabular}

${ }^{a}$ Fisher's exact test. ${ }^{b}$ Comparisons of proportions ( $\chi^{2}$ test). ${ }^{c}$ Comparisons of means ( $t$ test).

Table 3. Number of cells, sugar and protein in the CSF of high and low viral load group patients

\begin{tabular}{lcc}
\hline & $\begin{array}{l}\text { High HSV DNA } \\
\text { load group }\end{array}$ & $\begin{array}{l}\text { Low HSV DNA } \\
\text { load group }\end{array}$ \\
\hline Total leukocyte count & $0-500$ & $0-250$ \\
Polymorphs, \% & $1-2$ & $1-2$ \\
Lymphocytes, \% & $0-100$ & $0-98$ \\
Sugar, mg/dl & $32.48-86.35$ & $40.61-106.2$ \\
Protein, mg/dl & $39.46-167.2$ & $26.68-123.6$ \\
\hline
\end{tabular}

comparison to the higher viral load group. Thus, the number of cases with detectable lesions in the brain as revealed by CT/MRI scan procedures were significantly more $(84.61 \%)$ in the higher viral load group when compared with the lower viral load group $(p=0.0048)$. Ab- normalities revealed by CT included hypodensities involving temporal lobe and occipital lobes, parafalcine frontal cortex, cerebellum, thalami and corona radiata. MRI showed gyral edema, hyperintensities in cingulate gyrus, hippocampus, insular/parietal/parasagittal/parafalcine/perisylvian cortex and temporal or frontal lobe lesions. There were 7 out of 25 patients, 2 in the low viral load group and 5 in the high viral load group, in whom the lesions were visible in MRI only, while the CT was found to be normal. The assessment of clinical outcome showed that 11 patients $(84.61 \%)$ in the high viral load group had moderate levels of impairment, 1 (7.69\%) returned to normal function, whereas 1 patient $(7.69 \%)$ died and the other (7.69\%) had severe levels of impairment. In the low viral load group, 7 patients (58.33\%) regained normal function, $4(33.33 \%)$ had mild to moderate levels of impairment, whereas 1 patient $(8.33 \%)$ died. Other clinical parameters such as seizures, vomiting and headache and extent of neurological impairment using the Glasgow Coma Scale were also determined in the patients. However, no significant variation was obtained between the two groups.

CSF in the patients of both the group was analyzed for total leukocyte count, polymorphs, lymphocytes, eosinophils, monocytes, sugar, and protein (table 3).

For the determination of the detection limit of a known amount of HSV-1 and HSV-2, DNA standards were taken separately in tenfold serial dilutions from $10^{6}$ to $10^{1}$ copies of HSV-1 and HSV-2 genome. The limit of detection was found to be 10 copies of HSV genome to be detected by both the assays. The cross-reactivity of primers of both the viruses was checked by subjecting from $10^{6}$ to $10^{1}$ copies of HSV-1 to be amplified in the presence of HSV-2 primers and vice versa, respectively. The meltcurve analysis of the real-time PCR assay showed a $\mathrm{T}_{\mathrm{m}}$ of 84.5-85.0 $0^{\circ}$ for HSV-1 DNA and 85.5-86.0 ${ }^{\circ}$ for HSV-2 DNA. Out of 102 HSE suspected CSF samples, 25 samples positive by qPCR assay of the DNA polymerase gene target were also found to be positive by HSV-1 PCR assay, whereas none of the samples were positive by HSV-2 PCR assay. In the $140 \mathrm{CSF}$ samples from patients with other CNS infectious or non-infectious neurological disorders tested by both the assays, none was found to be positive for the presence of HSV-1 or HSV-2.

Consecutive CSF samples were obtained from 4 patients, 2 each in the high and low viral load group. As shown in table 4 , there was a decline in the viral load of patients on acyclovir treatment, with a marked decrease obtained on collection of CSF samples on the 7th and 12 th days of treatment in patients 1 and 10, respectively, 
Table 4. Quantity of HSV DNA per milliliter of CSF according to duration of acyclovir therapy from patients of the high viral load group (patients 1 and 10) and of the low viral load group (patients 19 and 22); the limit of detection of the assay is 10 copies of HSV genome

\begin{tabular}{lcl}
\hline & $\begin{array}{l}\text { Sample collection } \\
\text { interval, days }\end{array}$ & $\begin{array}{l}\text { Viral load, } \\
\text { copies/ml of CSF }\end{array}$ \\
\hline $\begin{array}{l}\text { High HSV DNA } \\
\text { Patient } 1\end{array}$ & 1 & \\
& 7 & $4.1 \times 10^{6}$ \\
& 17 & $8.1 \times 10^{4}$ \\
Patient 10 & 1 & not detected \\
& 12 & $5 \times 10^{4}$ \\
& 31 & $3.2 \times 10^{3}$ \\
Low HSV DNA load group & not detected \\
Patient 19 & 1 & $1 \times 10^{2}$ \\
& 7 & not detected \\
Patient 22 & 1 & $9.9 \times 10^{2}$ \\
& 7 & $1 \times 10^{3}$ \\
\hline
\end{tabular}

in the high viral load group. In patient 19 of the low viral load group, there was a decrease in the viral load on the 7th day of acyclovir treatment, however the HSV copy number in patient 22 remained almost static after the 7 th day of acyclovir treatment.

\section{Discussion}

In the present study, gender, age, duration of disease and severity of disease were compared between patients with amounts of HSV DNA $<10^{4}$ or $>10^{4}$ copies $/ \mathrm{ml}$ of CSF. A more severe disease was found in the group of patients with $>10^{4} \mathrm{HSV}$ copies/ml of CSF. The number of patients with lesions in the brain seen by CT/MRI scan were more in the high viral load group compared to the low viral load group, and the difference was statistically significant $(\mathrm{p}=0.0048)$. CT/MRI increases the likelihood of a positive PCR, however patients with such findings can be negative by PCR and some PCR-positive patients with less severe forms of HSE have normal CT scans [19]. The duration of onset of disease before the CSF had been collected was almost two times longer in the group of patients with $\geq 10^{4} \mathrm{HSV}$ DNA copies/ml of CSF. These data confirm the need for the early introduction of antiviral treatment in order to reduce the amount of virus replicating within the CNS and improve the clinical outcome [20]. The number of days for which acyclovir had to be administered $(p=0.0028)$ and the patient had to be con- servatively managed in the hospital so as to achieve an improved outcome of the patients, were significantly more in the patients of the high viral load group than in the low viral load group. After completion of treatment, nearly $85 \%$ of the individuals in the high viral load group had moderate levels of impairment, suggesting that there are more chances that the patient would develop severe neurological sequelae in correlation to viral load and that even death can occur in some cases. In the low viral load group, 7 patients $(58.33 \%)$ regained normal function while $4(33.33 \%)$ had mild to moderate levels of impairment, suggesting that either the early introduction of antiviral therapy (as duration of onset of disease before the CSF had been collected was almost two times lower in the group of patients with low viral load) or the low viral load resulted in minimal neurological sequelae in this group. One of the patients of the low viral group died in spite of acyclovir therapy, which could suggest the presence of drug-resistant HSV mutants in this individual as discussed below.

In this study, follow-up CSF specimens from 2 patients each both in the high and low viral load group were available for assessment of the response to antiviral therapy. A decline in the number of HSV copies presents a distinct clinical advantage in patients receiving antiviral medications, which helps to ensure adequate suppression of virus replication in order to monitor for the emergence of drugresistant HSV mutants. The number of cases of which serial samples were available is limited to draw valid conclusions from the results in this study. However, it was observed that the 2 patients of the higher viral load group required longer duration of acyclovir therapy so that the virus become undetectable by the qPCR assay in comparison to 1 patient of the lower viral load group who required shorter duration of therapy. The time taken for the clearance of viral load from CSF may reflect the differences in pathogenesis and host response. In this context, a study found that the greater the load of the organism, the longer the PCR remains positive in the serial samples of patients during the course of treatment [21]. The results were indicative of some association between the initial load of the organism and the duration of treatment. One of the patients of the low viral load group clinically responded well to the antiviral treatment with a decrease in the viral copy number, however the other showed an almost static number of virus particles in the CSF after the 7 th day of treatment. Viral drug resistance should be suspected and studied for patients with no decline in viral DNA levels. In this context, there are recent reports that have demonstrated a relationship between virus load and 
the propensity to develop drug-resistant mutants [22]. There are only two studies from India reporting the prevalence of acyclovir resistance among the studied HSV isolates $[23,24]$. Therefore, molecular studies such as qPCR assay could be adopted to determine the presence of resistant HSV isolates in this geographical location.

Quantitative analyses of viral load have been shown to be useful for the evaluation of human herpes virus infections of the CNS. It has been reported that the detection of HSV DNA in CSF by PCR represents a valuable tool for the early diagnosis of HSE. There are several studies reporting the PCR method as a rapid, sensitive and noninvasive means to diagnose HSE in comparison to that of a more invasive diagnostic approach, such as brain biopsy. PCR detection of HSV DNA in CSF specimens is considered as an emerging 'gold standard' for the laboratory diagnosis of CNS infections with this virus [25]. Real-time PCR has been introduced recently for the detection of HSV genomes in the CSF. In a study, a molecular assay based on real-time PCR on the LightCycler ${ }^{\circledR}$ instrument was evaluated for rapid detection and quantification of HSV DNA in the CSF. It has been shown that quantitation of HSV viral load may be useful for assessing the prognosis, and may provide additional information for the management of HSV infection [26]. Studies have been done for evaluating the role of real-time SYBR Green PCR compared to that of real-time TaqMan ${ }^{\circledR}$ assay and in two studies it was found that real-time SYBR Green PCR was equally sensitive in detecting dengue infection compared to real-time TaqMan assay, but the SYBR Green assay was found to be an economical alternative to TaqMan assay for diagnostic purposes as the use of SYBR Green reduced their material costs for diagnosis by half compared to other methods that used probes $[27,28]$. Another study reported that the SYBR Green-based assay was as sensitive as the TaqMan assay for West Nile virus, and it detected $100 \%$ of possible West Nile virus target region variants which TaqMan assay failed to detect [29]. SYBR Green-based qPCR provides a rapid, easy and accurate diagnosis of herpes virus CNS disease including viral load as supplementary information. However, in India as of today, HSE appears to be underdiagnosed, probably due to lack of awareness and sensitive diagnostic facilities. Epidemiological studies for viruses are not available in many parts of the country due to lack of virology research laboratories. Thus, the percentage of cases of viral encephalitis and proportion of HSE are difficult to estimate. There are no documented studies from India for the determination of viral load by real-time PCR in HSE patients. Nevertheless, a few studies have addressed the potential utility of quantitation of HSV DNA in CSF samples from HSE patients as a prognostic marker and for assessing the response to antiviral therapy. The results presented in this study provide observations regarding the diagnosis of HSE and the correlation of viral load with that of the patients' clinical and laboratory manifestations in a 4-year retrospective study undertaken in a hospital setting. There are two HSV genotypes (HSV-1 and -2) causing different clinical outcomes in different patient populations. Real-time analysis using type-specific primers revealed the presence of predominantly HSV-1 genotype in the study population.

\section{Conclusions}

The results show that the determination of viral load offers a definite advantage in the detection of the relatively lower levels of viremia (up to 10 copies of genome) and establish and compare the clinical characteristics of patients associated with the levels of HSV DNA in the CSF. It was found that significantly higher viral loads were clearly associated with the severity of neurological disease. In conclusion, the qPCR assay can be used as a prognostic marker since patients with higher viral loads of HSV-1 in their CSF are more likely to develop more severe neurological impairment while considering the presence of lesions, the duration of acyclovir therapy and clinical outcome of the disease at the time of completion of treatment. Viral load determination can be of potential utility for monitoring antiviral therapy in patients with HSE. A decline in the number of HSV copies was observed and the patients clinically responded to acyclovir therapy in the high viral load group. One of the patients of the low viral load group had an almost static number of virus particles in the CSF after treatment. This observation presents a distinct clinical advantage in patients receiving antiviral medications, which helps to ensure adequate suppression of virus replication in order to monitor for the emergence of drug-resistant HSV mutants.

\section{Acknowledgement}

The authors thank Shweta V. Deote for providing assistance in collecting the clinical data of the patients for the study.

\section{Disclosure Statement}

The authors have no conflicts of interest to disclose. DOI: $10.1159 / 000351521$
Bhullar/Chandak/Purohit/Taori/ Daginawala/Kashyap 


\section{References}

1 Puchhammer-Stöckl E, Popow-Kraupp T, Heinz FX, Mandl CW, Kunz C: Establishment of PCR for the early diagnosis of herpes simplex encephalitis. J Med Virol 1990;32:77-82.

2 Rowley AH, Wolinsky SM, Whitley RJ, Lakeman FD: Rapid detection of herpes simplex virus DNA in cerebrospinal fluid of patients with herpes simplex encephalitis. Lancet 1990;335:440-441.

-3 Aurelius E, Johansson B, Sköldenberg B, Staland A, Forsgren M: Rapid diagnosis of herpes simplex encephalitis by nested polymerase chain reaction assay of cerebrospinal fluid. Lancet 1991;337:189-192.

-4 Higuchi R, Dollinger G, Walsh PA, Griffith R: Simultaneous amplification and detection of specific DNA sequences. Biotechnology 1992; 10:413-417.

5 Weidmann M, Meyer-König U, Hufert FT: Rapid detection of herpes simplex virus and varicella-zoster virus infections by real-time PCR. J Clin Microbiol 2003;41:1565-1568.

-6 Kawada J, Kimura H, Ito Y, Hoshino Y, Tanaka-Kitajima N, Ando Y, Futamura M, Morishima T: Comparison of real-time and nested PCR assays for detection of herpes simplex virus DNA. Microbiol Immunol 2004;48: 411-415.

-7 Kessler HH, Mühlbauer G, Rinner B, Stelzl E, Berger A, Dörr HW, Santner B, Marth E, Rabenau $\mathrm{H}$ : Detection of herpes simplex virus DNA by real-time PCR. J Clin Microbiol 2000;38:2638-2642.

-8 Kimura H, Ito Y, Futamura M, Ando Y, Yabuta Y, Hoshino Y, Nishiyama Y, Morishima T: Quantitation of viral load in neonatal herpes simplex virus infection and comparison between type 1 and type 2. J Med Virol 2002;67: 349-353.

9 Murphy RF, Caliendo AM: Relative quantity of cerebrospinal fluid herpes simplex virus DNA in adult cases of encephalitis and meningitis. Am J Clin Pathol 2009;132:687-690.

10 Ryncarz AJ, Goddard J, Wald A, Huang ML, Roizman B, Corey L: Development of a highthroughput quantitative assay for detecting herpes simplex virus DNA in clinical samples. J Clin Microbiol 1999;37:1941-1947.

-11 Muñoz-Almagro C, Jordan I, Cambra FJ, Esteban E, Urrea M, Garcia-Garcia JJ, Palomeque A: Quantitative real-time PCR in paediatric patients with herpes simplex infections of the central nervous system. J Virol Methods 2008; 147:297-300.
12 Schloss L, Falk KI, Skoog E, Brytting M, Linde A, Aurelius E: Monitoring of herpes simplex virus DNA types 1 and 2 viral load in cerebrospinal fluid by real-time PCR in patients with herpes simplex encephalitis. J Med Virol 2009;81:1432-1437.

13 Satishchandra P, Nandini M, Shankar SK, Vasudevarao T, Ravi V, Shenoy PK, Chatterjee S, Jain S: Herpes simplex encephalitis: a diagnostic and therapeutic reappraisal. J Assoc Physicians India 1993;41:277-278

14 Panagariya A, Jain RS, Gupta S, Garg A, Sureka RK, Mathur V: Herpes simplex encephalitis in North West India. Neurol India 2001; 49:360-365.

15 Gambhir IS, Singh NN, Singh DS, Gulati AK: Herpes simplex virus- 1 encephalitis in eastern Uttar Pradesh. J Assoc Physicians India 1999;47:1149-1151.

16 Whitley RJ, Cobbs CG, Alford CA Jr, Soong SJ, Hirsch MS, Connor JD, Corey L, Hanley DF, Levin M, Powell DA: Diseases that mimic herpes simplex encephalitis. Diagnosis, presentation, and outcome. NIAD Collaborative Antiviral Study Group. JAMA 1989;262:234239.

17 Cunningham ET Jr, Short GA, Irvine AR, Duke JS, Margolis TP: Acquired immunodeficiency syndrome - associated herpes simplex virus retinits. Clinical description and use of a polymerase chain reaction based assay as a diagostic tool. Arch Opthalmol 1996;114:834840 .

18 Lakeman FD, Whitley RJ: Diagnosis of herpes simplex encephalitis: application of polymerase chain reaction to cerebrospinal fluid from brain-biopsied patients and correlation with disease. National Institute of Allergy and Infectious Diseases Collaborative Antiviral Study Group. J Infect Dis 1995;171:857-863.

19 Domingues RB, Tsanaclis AM, Pannuti CS, Mayo MS, Lakeman FD: Evaluation of the range of clinical presentations of herpes simplex encephalitis by using polymerase chain reaction assay of cerebrospinal fluid samples. Clin Infect Dis 1997;25:86-91.

20 Whitley RJ, Gnann JW Jr: Acyclovir: a decade later. N Engl J Med 1992;327:782-789. Erratum in N Engl J Med 1997;337:1703 \& N Engl J Med 1993;328:671.
21 Ziyaeyan M, Alborzi A, Borhani Haghighi A, Jamalidoust M, Moeini M, Pourabbas B: Diagnosis and quantitative detection of HSV DNA in samples from patients with suspected herpes simplex encephalitis. Braz J Infect Dis 2011;15:211-214.

22 Puchhammer-StöcklE, Mandl CW, Kletzmayr J, Holzmann H, Hofmann A, Aberle SW, Heinz FX, Watschinger B, Hofmann H: Monitoring the virus load can predict the emergence of drug-resistant hepatitis B virus strains in renal transplantation patients during lamivudine therapy. J Infect Dis 2000;181: 2063-2066.

23 Pramod NP, Thyagarajan SP, Mohan KV, Anandakannan K: Acyclovir resistance in herpes simplex virus isolates from keratitis cases: an analysis from a developing country. Microbiol Immunol 2000;44:241-247.

24 Abraham AM, Kavitha S, Joseph P, George R, Pillay D, Malathi J, Jesudason MV, Sridharan G: Acyclovir resistance among Indian strains of herpes simplex virus as determined using a dye uptake assay. Indian J Med Microbiol 2007;25:260-262.

25 Mitchell PS, Espy MJ, Smith TF, Toal DR, Rys PN, Berbari EF, Osmon DR, Persing DH: Laboratory diagnosis of central nervous system infections with herpes simplex virus by PCR performed with cerebrospinal fluid specimens. J Clin Microbiol 1997;35:2873-2877.

26 Domingues RB, Lakeman FD, Mayo MS, Whitley RJ: Application of competitive PCR to cerebrospinal fluid samples from patients with herpes simplex encephalitis. J Clin Microbiol 1998;36:2229-2234.

27 Gomes-Ruiz AC, Nascimento RT, de Paula SO, Lopes da Fonseca BA: SYBR Green and TaqMan real-time PCR assays are equivalent for the diagnosis of dengue virus type 3 infections. J Med Virol 2006;78:760-763.

28 Paudel D, Jarman R, Limkittikul K, Klungthong C, Chamnanchanunt S, Nisalak A, Gibbons R, Chokejindachai W: Comparison of real-time SYBR Green dengue assay with realtime TaqMan RT-PCR dengue assay and the conventional nested PCR for diagnosis of primary and secondary dengue infection. N Am J Med Sci 2011;3:478-485.

29 Papin JF, Vahrson W, Dittmer DP: SYBR Green-based real-time quantitative PCR assay for detection of West Nile virus circumvents false-negative results due to strain variability. J Clin Microbiol 2004;42:1511-1518. 